\title{
Tropospheric column ozone response to ENSO in GEOS-5 assimilation of OMI and MLS ozone data
}

\author{
Mark A. Olsen ${ }^{1,2}$, Krzysztof Wargan ${ }^{3,4}$, and Steven Pawson ${ }^{3}$ \\ ${ }^{1}$ Atmospheric Chemistry and Dynamics Laboratory, Code 614, NASA Goddard Space Flight Center, Greenbelt, MD, USA \\ ${ }^{2}$ Goddard Earth Science, Technology and Research Center, Morgan State University, Baltimore, MD, USA \\ ${ }^{3}$ Global Modeling and Assimilation Office, Code 610.1, NASA Goddard Space Flight Center, Greenbelt, MD, USA \\ ${ }^{4}$ Science Systems and Applications Inc., Lanham, MD, USA
}

Correspondence to: Mark A. Olsen (mark.olsen@nasa.gov)

Received: 24 November 2015 - Published in Atmos. Chem. Phys. Discuss.: 18 January 2016

Revised: 26 April 2016 - Accepted: 13 May 2016 - Published: 10 June 2016

\begin{abstract}
We use GEOS-5 analyses of Ozone Monitoring Instrument (OMI) and Microwave Limb Sounder (MLS) ozone observations to investigate the magnitude and spatial distribution of the El Niño Southern Oscillation (ENSO) influence on tropospheric column ozone (TCO) into the middle latitudes. This study provides the first explicit spatially resolved characterization of the ENSO influence and demonstrates coherent patterns and teleconnections impacting the TCO in the extratropics. The response is evaluated and characterized by both the variance explained and sensitivity of TCO to the Niño 3.4 index. The tropospheric response in the tropics agrees well with previous studies and verifies the analyses. A two-lobed response symmetric about the Equator in the western Pacific/Indonesian region seen in some prior studies and not in others is confirmed here. This two-lobed response is consistent with the large-scale vertical transport. We also find that the large-scale transport in the tropics dominates the response compared to the small-scale convective transport. The ozone response is weaker in the middle latitudes, but a significant explained variance of the TCO is found over several small regions, including the central United States. However, the sensitivity of TCO to the Niño 3.4 index is statistically significant over a large area of the middle latitudes. The sensitivity maxima and minima coincide with anomalous anti-cyclonic and cyclonic circulations where the associated vertical transport is consistent with the sign of the sensitivity. Also, ENSO related changes to the mean tropopause height can contribute significantly to the midlatitude response. Comparisons to a 22 -year chemical transport model simulation demonstrate that these results from the 9-
\end{abstract}

year assimilation are representative of the longer term. This investigation brings insight to several seemingly disparate prior studies of the El Niño influence on tropospheric ozone in the middle latitudes.

\section{Introduction}

The contributions by natural phenomena to tropospheric ozone variability must be identified and quantified for robust assessments of the present and future anthropogenic influence. Here, we investigate the signal of the El Niño Southern Oscillation (ENSO) in extratropical tropospheric ozone in a global assimilation system. To the best of our knowledge, this study provides the first near-global, explicit, spatially resolved characterization of the ENSO influence, and reveals coherent patterns and mechanisms of the influence in the extratropics.

ENSO is well known to impact the magnitude of tropospheric ozone in the tropical Pacific. El Niño (La Niña) conditions are characterized by anomalous increases (decreases) in SSTs in the central and eastern Pacific. Opposite anomalies tend to occur in the western Pacific. In general, changes to convection and circulation patterns under El Niño conditions lead to reduced tropical tropospheric ozone in the central and eastern Pacific and enhanced ozone over the western Pacific and Indian Oceans. The response is highly linear in the tropics, so La Niña conditions produce an antisymmetric response (DeWeaver and Nigam, 2002). This influence on tropical tropospheric ozone has been observed in 
satellite data (e.g., Chandra et al., 1998; Thompson et al., 2001; Ziemke et al., 2010, 2015) and ground-based measurements (e.g., Fujiwara et al., 1999; Lee et al., 2010). Both chemical transport models (CTMs) driven by analyzed meteorology and free-running models have simulated this impact of ENSO on the tropical ozone (e.g., Sudo and Takahashi, 2001; Zeng and Pyle, 2005; Doherty et al., 2006; Oman et al., 2011).

The ENSO impact has also been demonstrated to extend to the subtropics. Using 40 years of ozone observations at Mauna Loa Observatory and a CTM, Lin et al. (2014) identified a strong link between El Niño events and lower tropospheric ozone enhancements over the subtropical eastern Pacific in winter and spring. They attribute this to the eastward extension and the equatorward shift of the subtropical jet stream during El Niño, which enhances the longrange transport of Asian pollution. Neu et al. (2014) examined mid-tropospheric ozone observations from TES during 2005-2010 and found increased and decreased zonal mean ozone below the Northern Hemisphere climatological subtropical jet during the 2009-2010 El Niño and 2007-2008 La Niña, respectively.

In the extratropics, ENSO events have been shown to alter the circulation by modifying planetary wave driving, the North Pacific low, and the location and strength of the extratropical jets (e.g., Angell and Korshover, 1984; Langford, 1999; Trenberth et al., 2002; García-Herrera et al., 2006). Thus, it is reasonable to expect ENSO to have a dynamical impact on extratropical tropospheric ozone distribution and variability. However, the extratropical ozone response to ENSO has not been as extensively studied as the tropical ozone response and some results from prior studies appear to be contradictory. Oman et al. (2013) examined the ozone sensitivity to ENSO with Microwave Limb Sounder (MLS) and Tropospheric Emission Spectrometer (TES) observations in addition to a chemical-climate model simulation. Although limited by just over 5 years of TES data (September 2004 through December 2009), they show statistically significant sensitivity in the lower midlatitude troposphere over two broad meridional bands centered on the Pacific and Indian Oceans. Balashov et al. (2014) find a correlation between ENSO and tropospheric ozone around South Africa using air quality monitoring station data from the early 1990s to the 2000s. Langford et al. (1998) and Langford (1999) show ozone enhancements in the free troposphere correlated with El Niño (with a several month lag) in lidar data from Boulder, Colorado between 1993 and 1998. Langford (1999) attributes this to the secondary circulation associated with an eastward shifted Pacific subtropical jet exit region under El Niño conditions. The transverse circulation of ozone-rich air from the stratosphere across the jet is then transported poleward. Lin et al. (2015) conclude that more frequent springtime stratospheric intrusions following La Niña winters contribute to increased ozone at the surface and free troposphere in the western United States.
In contrast, other observational and modeling studies have not found a significant relationship between ENSO and extratropical tropospheric ozone, suggesting that any such influence is weak or occurs only on a regional scale. For example, Vigouroux et al. (2015) use a stepwise multiple regression model including an ENSO proxy to examine ground-based Fourier transform infrared (FTIR) measurements from eight subtropical and extratropical stations of the Network for the Detection of Atmospheric Composition Change (NDACC). They did not find a significant ENSO impact on the tropospheric ozone column at any of the eight sites. Hess et al. (2015) also did not find a relation between ENSO and tropospheric ozone over extratropical regions in a four-member ensemble model simulation spanning 1953 to 2005. They suggest that ENSO may occasionally induce ozone anomalies but the correlation is weak. Thompson et al. (2014) remove the ENSO signal from ozonesonde data near South Africa to investigate middle tropospheric ozone trends. However, in contrast to the results of Balashov et al. (2014) using air quality station data, they find the correlation of the sonde data with ENSO is weak (A. Thompson, personal communication, 2016).

Determining the spatial extent of ENSO influence on tropospheric ozone from observations is difficult due to the sparse observation networks of sondes, FTIR, etc. The direct retrieval of tropospheric ozone from satellite observations is limited by coarse vertical resolution in the troposphere for nadir-viewing instruments and pressure broadening in the lower troposphere for limb-type instruments. Nevertheless, sonde and surface data combined with satellite observations have been used to derive a coarse global climatology of tropospheric ozone (Logan, 1999). Tropospheric ozone fields have also been derived from subtracting measured stratospheric column ozone from total column ozone (e.g., Fishman et al., 1990, 2003; Ziemke et al., 1998; Schoeberl et al., 2007). These residual methods are more robust at lower latitudes and have been used to show a large impact by ENSO on tropospheric ozone in the tropics (e.g., Chandra et al., 1998; Ziemke et al., 1998; Thompson and Hudson, 1999; Ziemke and Chandra, 2003; Fishman et al., 2005).

The goal of this paper is to use NASA's Goddard Earth Observing System Version 5 (GEOS-5) analyses of satellite measured ozone to investigate the spatial distribution, magnitude, and attribution of the tropospheric ozone response to ENSO. Assimilation provides the advantages of global, gridded fields constrained by observations. Ziemke et al. (2014) show that the ozone assimilation offers more robust tropospheric ozone fields for science applications in the lower and middle latitudes than residual methods. In the present study, the response in the tropics is evaluated and discussed alongside the midlatitude response. The relatively well-established tropical response is primarily included here for verification of the analyses, although several new findings are discussed. The comprehensive examination of the midlatitudes made possible by the ozone assimilation is novel to this study. In 
the midlatitudes, we show the tropospheric column ozone (TCO) has a statistically significant response to ENSO in some regions. This response can be explained by changes to circulation, convection, and tropopause height. These results will benefit both process-oriented evaluations of the regional ozone response in simulations and assessments of the anthropogenic impact on tropospheric ozone, including prediction of future tropospheric ozone and trends.

The following section discusses the data, assimilation system, and methods used in this study. The results are then presented in Sect. 3. A comparison of results to a CTM simulation is included to show that the 9-year time period of the EOS Aura observations is largely representative of longer periods. Additional discussion of the results is found in Sect. 4 before concluding with a brief summary.

\section{Data, assimilation system, and methods}

The ozone analyses used in this study were produced using a version of NASA's GEOS-5 data assimilation system (DAS), ingesting data from the Ozone Monitoring Instrument (OMI) and MLS on the Earth Observing System Aura satellite (EOS Aura), as described in Wargan et al. (2015). A brief description of the ozone data and assimilation system is provided in the following subsection. Subsequent subsections provide information on ancillary data sets used and the linear regression analysis used in this study.

\subsection{Ozone data and GEOS-5 data assimilation system}

The OMI and MLS instruments are both onboard the polar orbiting EOS Aura satellite launched on 15 July 2004. $\mathrm{OMI}$ is a nadir-viewing instrument that retrieves near-total column ozone across a 60 -scene swath perpendicular to the orbit (Levelt et al., 2006). The footprint, or spatial resolution, of the nadir scene is $13 \mathrm{~km}$ along the orbital path by $24 \mathrm{~km}$ across the track. The cross-track scene width increases with distance from nadir to about $180 \mathrm{~km}$ at the end rows. OMI collection 3, version 8.5 retrieval algorithm data are used in the analyses considered here. The MLS instrument scans the atmospheric limb to retrieve the ozone vertical profile from microwave emissions. Version 3.3 data on the 38 layers between 261 and $0.02 \mathrm{hPa}$ were used in the present analyses after screening based upon established guidelines (Livesey et al., 2011).

The GEOS-5.7.2 version of the data assimilation system is used to produce the ozone analyses. This is a modified version from the system used in the Modern-Era Retrospective analysis for Research and Applications (MERRA) (Rienecker et al., 2011). For the analyses used here, the system uses a $2.5^{\circ} \times 2.0^{\circ}$ longitude-latitude grid with 72 layers from the surface to $0.01 \mathrm{hPa}$. The vertical resolution around the tropopause is about $1 \mathrm{~km}$. Alongside the ozone data, a large number of in situ and space-based observations are included in the GEOS-5 analyses (Wargan et al., 2015). However, OMI and MLS ozone retrievals are the only data that directly modify the analysis ozone in this version of the DAS. Anthropogenic and biomass burning ozone production sources are not explicitly implemented in these analyses. Although tropospheric chemistry is not implemented in the assimilation system, ozone that is produced or lost due to emissions and other tropospheric chemistry sources and sinks is included in the analyses to the extent of the sensitivity of each OMI column retrieval at tropospheric altitudes. In general, the sensitivity decreases with decreasing altitude in the troposphere. Wargan et al. (2015) provides more details on the OMI tropospheric sensitivity and the retrieval "efficiency factors", or averaging kernels, used in the assimilation.

Wargan et al. (2015) and Ziemke et al. (2014) previously evaluated these ozone analyses relative to sondes and other satellite data. Their assessments show that accounting for measurement and model errors in the assimilation greatly increases the precision of the tropospheric ozone over other methods of obtaining gridded TCO fields. Both Wargan et al. (2015) and Ziemke et al. (2014) show that there is greater disagreement of the tropospheric ozone analyses with sondes at high latitudes. For this reason, we restrict our discussion in the present study to the tropics and middle latitudes.

\subsection{Global modeling initiative CTM simulation}

We use a Global Modeling Initiative (GMI) CTM (Strahan et al., 2007; Duncan et al., 2008) simulation to determine if the results from the 9 years of ozone analyses are representative of the longer term. Stratospheric and tropospheric chemistry are combined in the GMI CTM with 124 species and over 400 chemical reactions. The tropospheric chemistry mechanism is a modified version originally from the GEOSCHEM CTM (Bey et al., 2001). The simulation is driven using MERRA meteorological fields for 1991-2012 and run at the same resolution as the assimilation system. Observationbased, monthly varying anthropogenic and biomass burning emissions are used through 2010 with repeated 2010 monthly means for the final 2 years. Strode et al. (2015) provide more details on this specific simulation, which they refer to as the "standard hindcast simulation" in their study. Ziemke et al. (2014) show that the TCO from a similar GMI simulation compares well with sonde observations. In the present study we define, process, and analyze the CTM TCO fields in the same manner as the assimilation fields.

\subsection{ENSO index and outgoing longwave radiation data}

ENSO is characterized in this study by the monthly mean Niño 3.4 index available from the NOAA Climate Prediction Center (Climate Prediction Center, 2016). The index is based upon the mean tropical sea surface temperature between $5^{\circ} \mathrm{N}-5^{\circ} \mathrm{S}$ and $170-120^{\circ} \mathrm{W}$. This time series is normalized using $1981-2010$ as the base time period. Figure 1 shows the 


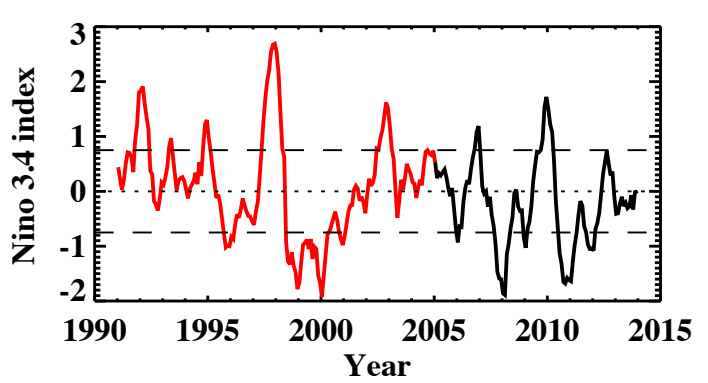

Figure 1. Time series of the Niño 3.4 index (K) from 1991 through 2013. The time period of ozone analyses is the black line (20052013). The red line indicates the additional years covered by the GMI simulation. Dashed lines are +0.75 and -0.75 that are considered strong El Niño and La Niña conditions in this study.

index time series from 1991 to 2013, which spans the years of the ozone analyses and GMI simulation. In this study, we define months with "strong" El Niño and La Niña conditions as months with index values greater than 0.75 and less than -0.75 , respectively. The Climate Prediction Center uses threshold values of 0.5 and -0.5 to characterize El Niño and La Niña, respectively. The value of \pm 0.75 used here to characterize months of "strong" conditions is about 1 standard deviation (0.78) of the time series spanning the assimilation, 2005-2013. La Niña conditions were dominant during the ozone analyses time period (black line in Fig. 1). Months of strong El Niño conditions occurred in the boreal fall/winter of 2006/2007 and 2009/2010. Months of strong La Niña conditions occurred during the boreal fall/winter of 2005/2006, 2007/2008, 2008/2009, 2010/2011, and 2011/2012.

We use outgoing longwave radiation (OLR) data as a proxy for convection to investigate the contribution from changes in convection associated with ENSO. The monthly, $1^{\circ} \times 1^{\circ}$ data are provided by the NOAA Earth System Research Laboratory (Lee, 2014). Small values of OLR indicate substantial convection, and vice versa.

\subsection{Methods}

For the present study, we use the 9 full years (2005-2013) of ozone analyses that have been completed. To calculate the TCO, we define the tropopause at each grid point as the lower of the $380 \mathrm{~K}$ potential temperature and 3.5 potential vorticity unit (1 PVU $\left.=10^{-6} \mathrm{~m}^{2} \mathrm{~K} \mathrm{~kg}^{-1} \mathrm{~s}^{-1}\right)$ surfaces. The daily TCO fields are smoothed horizontally by averaging each grid point with the eight adjacent neighboring points. Monthly mean TCO is computed from the daily values. We deseasonalize the TCO to remove the large seasonal variability by subtracting the respective 9-year mean for each month at each point.

We use multiple linear regression of the TCO monthly mean time series onto the Niño 3.4 index and the first four sine and cosine harmonics to evaluate the response of tropospheric ozone to ENSO. That is, $\mathrm{TCO}=\sum_{i} m_{i} X_{i}+\varepsilon$, where

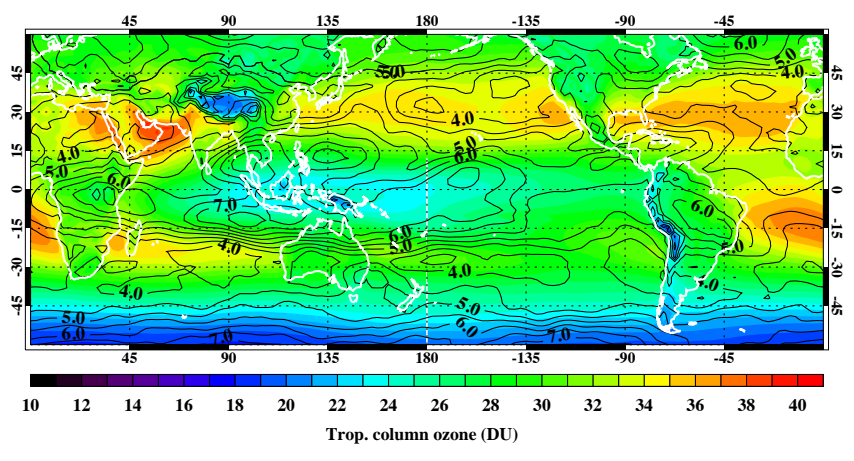

Figure 2. The 2005-2013 annual mean TCO (color contours) from the analyses. Black contours indicate one standard deviation of the deseasonalized TCO expressed as a percent of the annual mean TCO. Black contour interval is $0.5 \%$.

the $X_{i}$ are the index and harmonic time series, $m_{i}$ are the best fit regression coefficients, and $\varepsilon$ is the residual error. The regression is computed at every model grid point. The F-test is used to compute the confidence level of the explained variances (Draper and Smith, 1998). The calculated significance of the ozone sensitivity includes the impact from any autocorrelation in the residual time series (Tiao et al., 1990). We find that tests with time-lagged regressions from 1 to 6 months were generally no better than for zero-lag regressions. Therefore, the results presented herein are computed with no lag of the ozone time series. This is further discussed in Sect. 4.

\section{Results}

In this section, we examine the magnitude, spatial distribution, and mechanisms of the TCO response to ENSO. For reference, the multi-year annual mean TCO is shown in Fig. 2. The non-seasonal variability is indicated by overlaid contours of 1 standard deviation of the deseasonalized TCO expressed as a percent of the mean TCO. (Ziemke et al., 2014 illustrate the large seasonal variability). The following two subsections present the explained variance and TCO sensitivity to the Niño 3.4 index. Changes to advection and convection contributing to the TCO response are examined in Sects. 3.3 and 3.4. Section 3.5 evaluates the ENSOassociated changes to the tropopause height and the impact on the TCO response. We conclude this section with a comparison to CTM results in subsection 3.6 for the purpose of evaluating how robust the results from 9 years of ozone assimilation are compared to the longer term.

\subsection{Explained variance}

The percent variance of TCO explained by ENSO is shown in Fig. 3. The ENSO influence is greatest in the tropical Pacific where the variance explained has a maximum of about $55 \%$. This well-known tropical response is associated with 


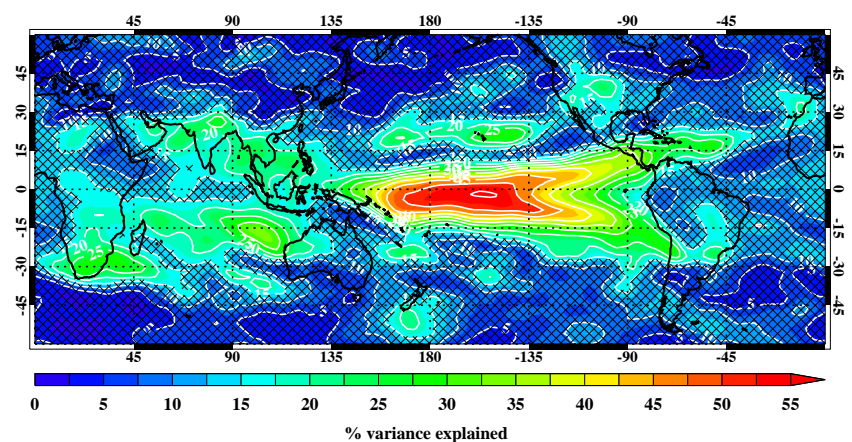

Figure 3. The deseasonalized TCO variance explained by ENSO from the linear regression over 2005-2013. Crosshatched areas denote where the confidence level of the explained variance being different from zero is less than $95 \%$. The increment of the white contours is $5 \%$.

increased convection and upwelling in the central and eastern Pacific during El Niño that lofts ozone-poor air into the mid- to upper-troposphere. The anomalous warm ocean current that runs southward along the South American coast during El Niño conditions (e.g., Trenberth, 1997) is evident in the tropospheric ozone response. A northeastward tongue of relatively large magnitude also extends towards and across Central America. An isolated significant maximum is also found between 20 and $30^{\circ} \mathrm{N}$ in the subtropical Pacific with explained variance of greater than $20 \%$.

In the western Pacific and Indonesian region, ENSO is known to produce an opposite response to the central and eastern Pacific due to increased upward transport during La Niña conditions. Two lobes of significant explained variance of more than $20 \%$ are symmetric around the equator in this region. Off the western coast of Australia, the southern lobe has a maximum of about $35 \%$.

The impact by ENSO is less in the subtropics and middle latitudes compared to the tropical Pacific. Still, the variance explained by ENSO is greater than $20 \%$ and statistically significant in several isolated regions. Of particular note, the variance explained exceeds $25 \%$ over South Africa and $20 \%$ over the central United States. These areas correspond to locations where previous studies have found an ENSO signature in ground station, FTIR, and ozonesonde data (Balashov et al., 2014; Langford et al., 1998; Langford, 1999; Lin et al., 2015). The variance explained also exceeds $20 \%$ in a small region south of New Zealand. Other midlatitude areas, such as the northern Pacific and Atlantic, exceed $10 \%$ but are not statistically significant due to the length of the time series.

\subsection{TCO sensitivity}

The sensitivity of TCO per degree change in the Niño 3.4 index is another measure of the ozone response to ENSO determined by the regression analysis. The spatial distribution of the sensitivity is shown in Fig. 4. Over the time period stud-

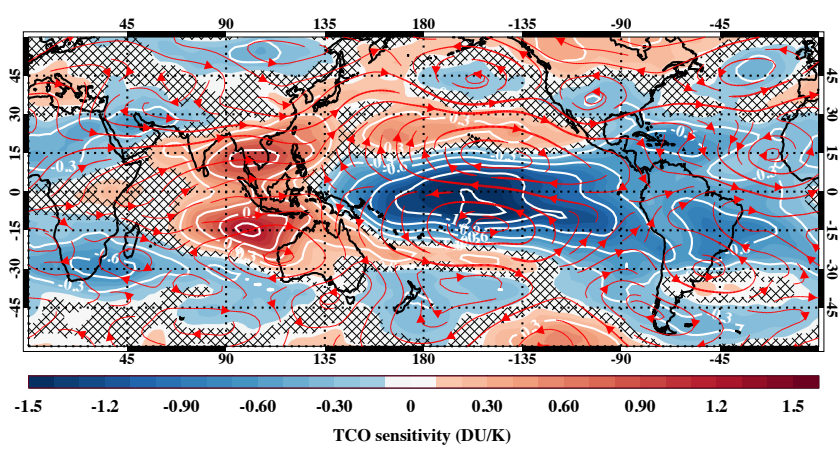

Figure 4. The TCO sensitivity to the Niño 3.4 index from the linear regression over 2005-2013 (color contours). The sensitivity is expressed as the change in the TCO per degree change in the index $\left(\mathrm{DU} \mathrm{K} \mathrm{K}^{-1}\right)$. Crosshatched regions denote where the sensitivity is not statistically different from zero at the $95 \%$ confidence level. White contours are incremented every $0.3 \mathrm{DU} \mathrm{K}^{-1}$. The streamlines show the difference between the mean winds at $200 \mathrm{hPa}$ for months with strong El Niño conditions (Niño 3.4 index greater than 0.75 ) minus months of strong La Niña conditions (Niño 3.4 index less than $-0.75)$. The thickness of the streamlines is scaled to the magnitude of the difference. Particularly note the midlatitude regions of negative and positive sensitivity aligned with anomalous cyclonic and anticyclonic circulations, as discussed in the text.

ied here, we find the response to be linear with respect to the ENSO forcing. The large region of negative sensitivity in the central Pacific corresponding to the maximum in explained variance is a result of the increased lofting of ozone-poor air into the middle and upper troposphere under El Niño conditions. Thus, higher values of the Niño 3.4 index correspond to decreases in the TCO. The opposite sensitivity is found in the equatorial symmetric lobes over Indonesia and the eastern Indian Ocean where the increased lofting (decreased TCO) occurs with La Niña (negative Niño 3.4 values). In the subtropics, positive sensitivity is located between about 20 and $30^{\circ}$ to the north and south of the large central Pacific minimum. In addition, relatively strong negative sensitivity exists over South Africa corresponding to the significant variance explained there. In the midlatitudes, a negative albeit weaker response is seen over the United States. Statistically significant negative responses are also found over the northern $\mathrm{Pa}$ cific and Atlantic Oceans, and the Southern Ocean.

\subsection{Changes in advection}

We examine the differences in circulation patterns for strong El Niño and La Niña conditions to investigate the large-scale impact of the extratropical circulation relative to the ozone sensitivity. The streamlines of the difference in the mean winds at $200 \mathrm{hPa}$ for months with Niño 3.4 index of greater than 0.75 and less than -0.75 are overlaid on the ozone sensitivity contours in Fig. 4. In the Northern Hemisphere extratropics, anomalous cyclonic circulations coincide with the regions of negative sensitivity over central Asia, the north 


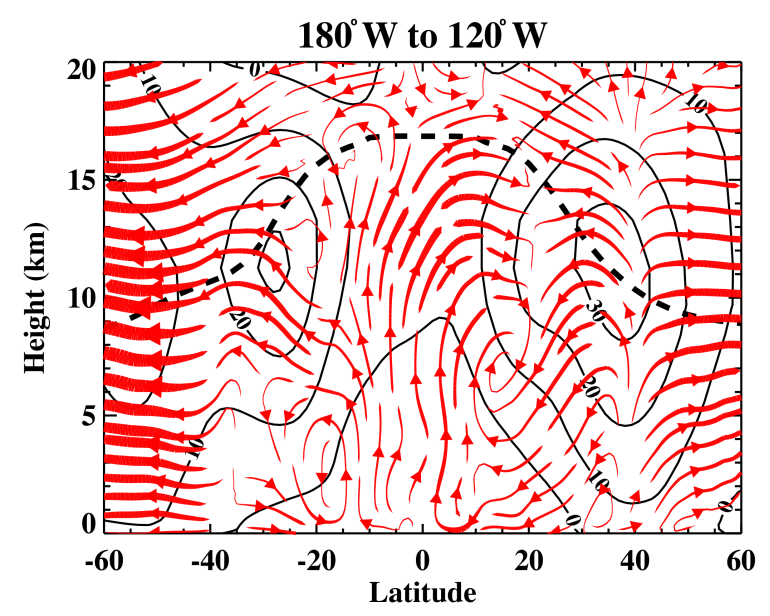

Figure 5. Streamlines of the difference between the mean vertical and meridional winds for months with strong El Niño conditions minus months of strong La Niña conditions from 2005 to 2013. The means are calculated between 180 and $120^{\circ} \mathrm{W}$. The width of the streamlines is proportional to the magnitude of the difference. The dashed line indicates the mean tropopause pressure for strong $\mathrm{El}$ Niño months. Solid contours are the zonal mean wind for strong El Niño months.

Pacific, United States, and the north Atlantic. The north Pacific and United States circulations agree well with ENSOassociated upper-troposphere height anomalies observed by Mo and Livezey (1986) and Trenberth et al. (1998). Similar cyclonic circulations aligned with negative sensitivity in the Southern Hemisphere are seen over the southern Pacific Ocean and over the southern tip of South America. Similarly, anomalous anticyclonic flow is associated with positive sensitivity over much of the midlatitudes.

The meridional and vertical cross-section streamlines of the difference between the mean winds between 180 and $120^{\circ} \mathrm{W}$ for months with Niño 3.4 index greater and less than 0.75 and -0.75 , respectively are shown in Fig. 5 . The positive and negative sensitivity patterns in this region shown in Fig. 4 coincide with the anomalous tropospheric downwelling and upwelling. In the tropics, the anomalous upwelling lofts ozone-poor air into the mid- and uppertroposphere in agreement with previous studies. Northward of about $40^{\circ} \mathrm{N}$, the tropospheric upwelling coincides with the cyclonic circulation and negative sensitivity shown in Fig. 4. This is consistent with increased upwelling induced by cyclonic circulation. Similarly, other anomalous cyclonic circulations associated with negative sensitivity over North America, the north Atlantic, and the southern tip of South America also correspond to regions of increased upwelling (not shown). The positive sensitivity between about 15 and $30^{\circ} \mathrm{N}$ corresponds with increased downwelling and evidence of increased cross-jet transport from the stratosphere into the troposphere in Fig. 5. Oman et al. (2013) find a similar positive sensitivity in this region and also in the Southern Hemisphere

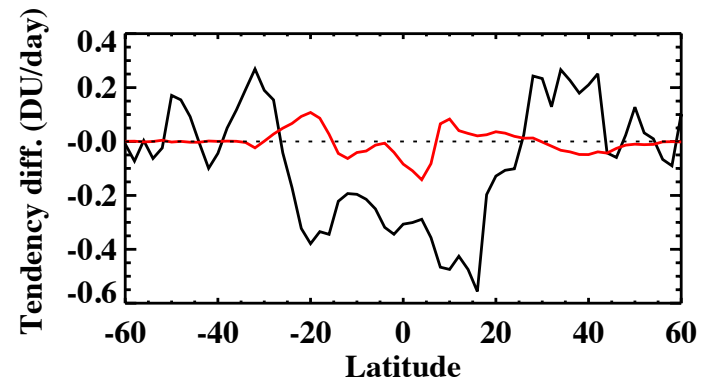

Figure 6. The dynamical (black) and convective (red) ozone tendency differences between months of strong El Niño and La Niña conditions from the assimilation system over 2005-2013. The means are calculated between 180 and $120^{\circ} \mathrm{W}$, matching that of Fig. 5.

subtropics in a GEOS-5 CCM simulation. In addition, Lin et al. (2014) find that increases in springtime ozone following El Niño at the Mauna Loa Observatory in Hawaii correspond to increased influence by Asian pollution. Here, the relative role of ozone-rich pollution transport cannot be distinguished from the cross-jet transport since emissions are not explicitly implemented in the assimilation. The extension of positive sensitivity contours upstream into the western Pacific to Asia in Fig. 4 is consistent with an influence by Asian emissions. However, El Niño and La Niña tend to peak in the Northern Hemisphere winter months when the emissions are least, which would reduce the potential influence.

The qualitative interpretation of the upwelling and downwelling shown in Fig. 5 is supported by comparison with the dynamical ozone tendency output by the assimilation system. Figure 6 shows the differences of the mean dynamical ozone tendencies averaged between 180 and $120^{\circ} \mathrm{W}$ for strong El Niño and La Niña months (the black line). The greatest differences occur in the mid to upper troposphere, so the net ozone tendencies are shown for the region between the tropopause and $350 \mathrm{hPa}$ below the tropopause, which provides a constant mass comparison. In the tropics, the El Niño-La Niña difference in the dynamical tendencies ranges between -0.2 to $-0.55 \mathrm{DU}$ day $^{-1}$, consistent with greater upward transport of ozone-poor air during El Niño than La Niña. In the lower extratropics, the dynamical tendency differences increase to around $0.2 \mathrm{DU} \mathrm{day}^{-1}$, corresponding with positive ENSO sensitivity in these regions and increased ozone during El Niño. Negative values of about $-0.1 \mathrm{DU} \mathrm{day}^{-1}$ exist between 40 and $50^{\circ}$ latitude that correspond with negative sensitivity and upwelling. The small magnitudes at these latitudes are about $1 / 6$ of the maximum tropical magnitude, which is consistent with the ratio of the sensitivities in these regions.

The positive sensitivity in the tropics around Indonesia corresponds with increased upwelling during La Niña conditions rather than with El Niño. This is evident in the downward oriented streamlines in Fig. 7 showing the circulation 


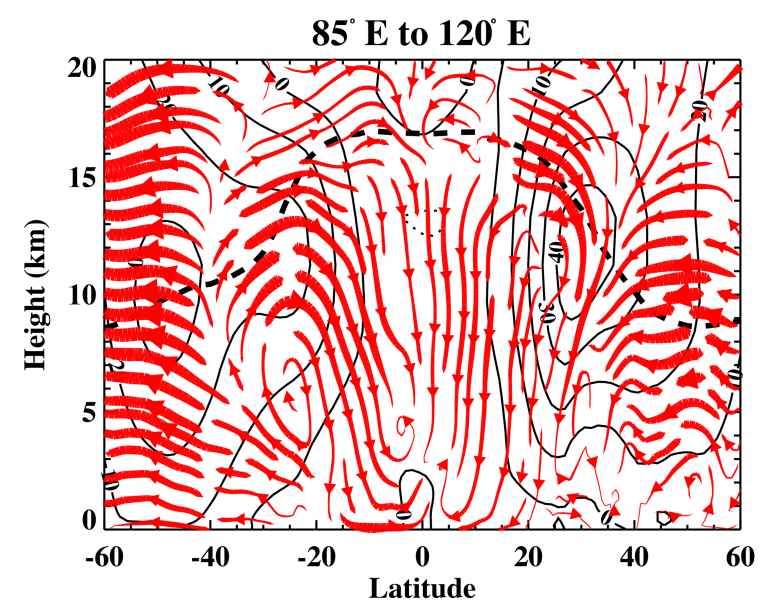

Figure 7. As in Fig. 5, but averaged between 85 and $120^{\circ}$ E.

differences averaged between 85 and $120^{\circ} \mathrm{E}$ for strong El Niño-La Niña months. In the tropics, the magnitude of the difference is smallest near the equator, resulting in the northern and southern tropical lobe structure of sensitivity maxima seen in Fig. 4. The difference is greater in the Southern Hemisphere and the streamlines indicate more stratosphere to troposphere transport than in the Northern Hemisphere as a possible reason for the greater sensitivity in the southern lobe located around $15^{\circ} \mathrm{S}$.

\subsection{Changes in convection}

In addition to the resolved advective vertical transport and stratosphere to troposphere transport, TCO can also respond to ENSO through changes in the vertical transport due to convection and mean depth of the tropospheric column (the tropopause height). This subsection examines the potential impact from convection using differences in OLR as a proxy. Changes in the tropopause height are presented in the following subsection.

The differences in the mean OLR for months with Niño 3.4 indices greater and less than 0.75 and -0.75 over the 9 years are shown in Fig. 8. The central Pacific is dominated by decreased OLR by up to $25 \%$, indicating greater convection under El Niño conditions. The maximum decrease is displaced to the west of the extrema of explained variance and TCO sensitivity to ENSO (Figs. 3 and 4, respectively). Over the Indonesian region, the OLR is increased by up to $16 \%$, indicating reduced convection. Here, the maximum OLR changes are offset to the east of the explained variance and sensitivity extrema.

These spatial offsets suggest that much of the tropical TCO sensitivity to ENSO is realized through the resolved advective transport. This is supported by the comparison of the analyses convective and dynamical tendency differences. Figure 6 compares the El Niño-La Niña differences in the analysis mid- to upper-tropospheric convective ozone ten-

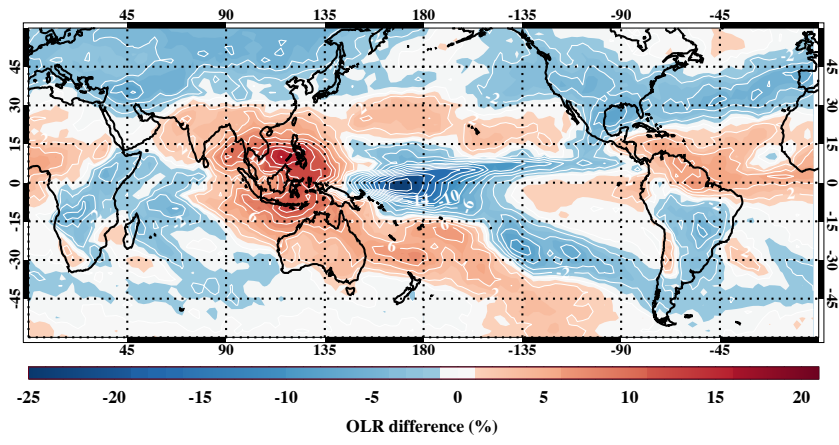

Figure 8. Difference in the outgoing longwave radiation (OLR) for months with strong El Niño conditions minus months of strong La Niña conditions from 2005-2013. The differences are expressed as percent of annual mean OLR. Thin white lines are incremented every $2 \%$.

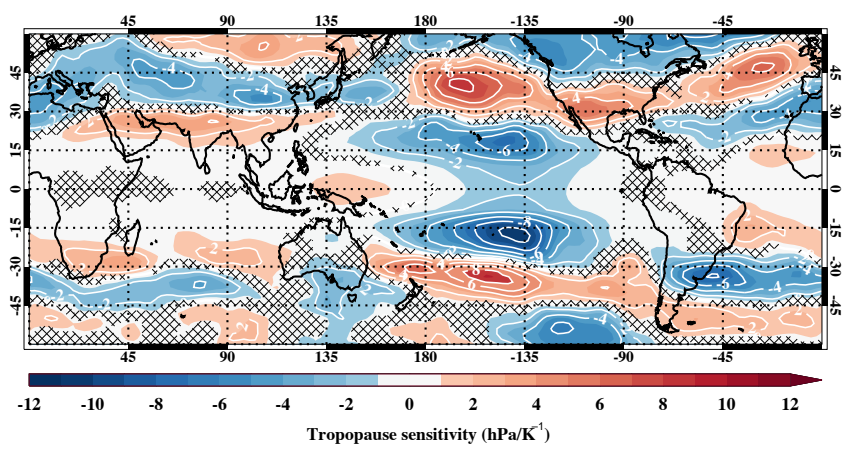

Figure 9. The sensitivity of tropopause pressure to the Niño 3.4 index from linear regression over 2005-2013. The sensitivity is expressed as the change in tropopause pressure per degree change in the index $\left(\mathrm{hPa} \mathrm{K}^{-1}\right)$. Crosshatched regions denote where the sensitivity is not statistically different from zero at the $95 \%$ confidence level. White contours are incremented every $2 \mathrm{hPa} \mathrm{K}^{-1}$.

dencies (red line) and dynamical tendencies (black line) between 180 and $120^{\circ} \mathrm{W}$. In the tropics, the convective tendency differences range from -0.15 to $0.1 \mathrm{DU}_{\text {day }^{-1}}{ }^{-1}$. The dynamical tendency differences are negative and the magnitudes are more than twice as great as the convective tendency differences. In the middle latitude north Pacific between 40 and $50^{\circ} \mathrm{N}$, the magnitude of the El Niño-La Niña convective ozone tendency difference is similar to the dynamical tendency differences (Fig. 6). Thus, the impact on the TCO sensitivity from the resolved transport and convection in this region are comparable in contrast to the tropics where the resolved transport is dominant.

\subsection{Impact from tropopause height differences}

The sensitivity of the tropopause pressure to the Niño 3.4 index determined by regression analysis is shown in Fig. 9. The response of the tropopause pressure is generally symmetric about the equator over the Pacific Ocean. Under El 
Niño conditions, a slightly greater mean tropopause pressure (decreased height and shorter tropospheric column) occurs in the extratropics poleward of the climatological subtropical jet. Equatorward, decreased tropopause pressures occur with El Niño, except in the western tropical Pacific where there is a small positive response. The pattern of tropopause response in the Pacific is similar to the $200 \mathrm{hPa}$ circulation anomalies in Fig. 4. The offset of the tropical response extrema to the north and south of the equatorial TCO response (Fig. 4) indicates that very little of the equatorial TCO response is attributable to changes in the depth of the tropospheric column. The maxima TCO response around $25^{\circ} \mathrm{N}$ and $25^{\circ} \mathrm{S}$ generally coincide with where the tropopause height response is zero. This also suggests that the positive TCO response here may be impacted by increased stratosphere to troposphere transport of ozone-rich air across the subtropical jet.

Changes in the depth of the tropospheric column associated with ENSO have a greater impact on the TCO sensitivity in the middle latitudes than in the tropics. Throughout much of the midlatitudes, positive tropopause pressure sensitivity coincides with negative TCO sensitivity and vice versa. Particularly noteworthy in the extratropical Northern Hemisphere are the positive tropopause pressure sensitivity maxima over the northern Pacific, North America, northern Atlantic, and Asia. The positive and negative tropopause sensitivity over extratropical South America also aligns closely to the TCO response.

Both the changes in transport (including vertical advection, convection, and cross-tropopause transport) and the tropopause height can impact the magnitude of TCO. We use regression analysis of the mean tropospheric mixing ratio on the Niño 3.4 index to make a rough estimate of the relative influences of transport and tropopause height changes. The mean mixing ratio is directly sensitive to changes in the transport but not to the tropopause pressure. Note that the mean mixing ratio also inherently includes any dependence from changes in chemistry that are associated with ENSO (Sudo and Takahashi, 2001; Stevenson et al., 2005; Doherty et al., 2006). If the response is assumed linear with respect to changes in transport/chemistry and tropospheric column depth, the variances explained by the TCO and mean mixing ratio can provide a first order estimate of the relative roles of these factors. For example, if the TCO explained variance in a region is $25 \%$ and the mixing ratio explained variance is $20 \%$, the tropopause height would account for an estimated $5 \%$, or $1 / 5$, of the TCO response.

The spatial pattern of the mean mixing ratio explained variance (not shown) is very similar to the TCO regression (Fig. 3) in both the tropics and midlatitudes. Throughout the tropics, the magnitudes of the variance explained are nearly identical. Thus, changes in transport/chemistry dominate the TCO response in this region. However, at middle latitudes the explained variance of mean mixing ratio is frequently less than that of the TCO, so the tropopause height plays a greater role. For the previously noted Northern Hemisphere negative

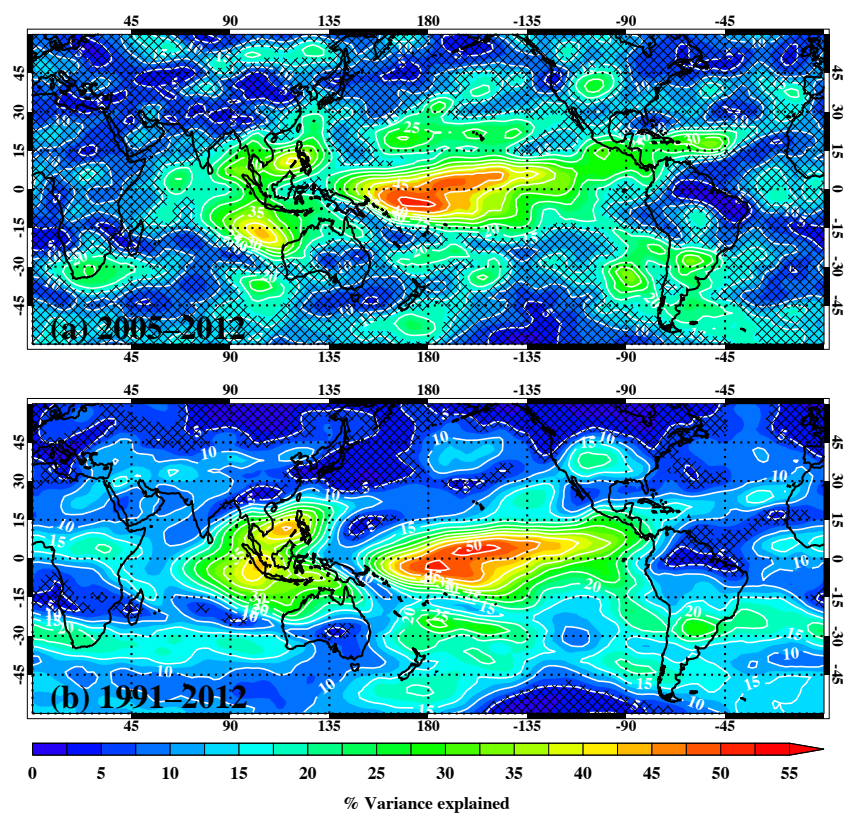

Figure 10. The deseasonalized TCO variance explained by ENSO in the GMI CTM simulation for years (a) 2005-2012 and (b) 19912012. Crosshatched areas denote where the confidence level of the explained variance being different from zero is less than $95 \%$. The increment of the white contours is $5 \%$.

sensitivity extrema, we estimate the tropopause height accounts for about a $1 / 4$ of the TCO response to ENSO over the United States, $1 / 2$ of the response over the North Pacific, and $2 / 3$ of the North Atlantic sensitivity. The tropopause height is responsible for about $1 / 5$ of the negative sensitivity around midlatitude South America. Also, only about $1 / 5$ or less of the positive TCO response in the subtropical Pacific around the climatological subtropical jets is attributable to changes in the tropopause height.

\subsection{Representativeness of the 9-year assimilation time series}

We use the 22-year (1991-2012) GMI CTM simulation described in Sect. 2.2 to show that the results from the 9 years of assimilation are representative of the longer-term TCO response to ENSO. The percentage of the simulated TCO variance explained by ENSO during 2005-2012 is shown in Fig. 10a for comparison with the assimilated ozone results over nearly the same time period (i.e., Fig. 3). The spatial distribution of the simulated TCO response is very similar. The maximum variance explained occurs in the central Pacific. The northeast and southeast split towards Central and South America is evident, but the southern fork is not as prominent. In the area of Indonesia, the simulated explained variance exhibits the same lobe-like structure symmetric about the equator. The maximum over the subtropical Pacific and isolated maxima over the United States and South Africa also 
agree well with the assimilated ozone results. Likewise, the ozone sensitivity to ENSO in the simulation is very similar to the results from the assimilation (not shown). The sensitivity patterns previously discussed relative to the assimilation are well represented in the simulation although the magnitude of the sensitivity is generally slightly greater in the simulation.

Regression analysis of the 22-year time span of the hindcast simulation reveals that much of the TCO response determined from the 9 years of assimilation is consistent with the longer-term response (Fig. 10b). Use of the longer time series also increases the area in which the explained variance is statistically different from zero, particularly in the middle latitudes. The shape and magnitude of the tropical explained variance is similar to the results from the shorter time period. Two differences are the reduced magnitude extending into the Northern Hemisphere Atlantic and the slight equatorward shift in the location of the Southern Hemispheric lobe in the Indonesian region. In the southern subtropical Pacific near $25^{\circ} \mathrm{S}$, the maximum in variance explained is more prominent. Conversely, the maximum in the northern subtropical Pacific is suppressed over the longer-term. However, there remains an enhancement of greater than $15 \%$ explained variance near $135^{\circ} \mathrm{W}$ between 15 and $30^{\circ} \mathrm{N}$ that is consistent with the shift in the exit region of the subtropical jet and the associated secondary circulation (Langford, 1999). Lin et al. (2014) find a strong ENSO signature in free tropospheric ozone from 40 years of observations over Mauna Loa. This is in the region where the variance explained is reduced in our 22-year simulation compared to the shorter assimilated and simulated time series. The simulated ozone sensitivity around Mauna Loa in the longer time series is very similar to the sensitivity found using the shorter time series (not shown). However, the TCO variability is greater over the longer time period, at least partially accounting for the reduced variance explained.

In the extratropical northern Pacific, corresponding to the location of negative sensitivity in Fig. 4, the explained variance is $10-15 \%$ and statistically significant. The signal over the United States and South Africa persists in the 22-year regression at over $20 \%$ explained variance. Over midlatitude Europe and Asia, the spatial pattern of the explained variance differs between the 22-year and 8-year regression results. This may be indicative of the variability and trends of emissions being much more dominant than the ENSO influence in this region.

\section{Discussion}

\subsection{Tropical response}

The tropical tropospheric ozone response to ENSO has been extensively studied in many previous observational and model investigations. The tropical response in the OMI/MLS ozone analyses agrees well with these prior investigations and verifies the analyses. However, many studies that evaluate the spatial distribution of the response do not show a twolobe structure in the western Pacific/Indonesian region as seen in the present study (e.g., Ziemke and Chandra, 2003). Nevertheless, our results confirm that the two-lobed response to the 2006 El Niño seen in OMI-MLS TCO residual fields by Chandra et al. (2009) and in TES observations by Nassar et al. (2009) is a robust response evident when considering more than that single event. Furthermore, Nassar et al. (2009) used a tropospheric CTM to show that this structure is predominantly of dynamical origin rather than from biomass burning emissions. The two-lobe structure is also suggested in the ozone sensitivity computed from regression of 5 years of TES data shown by Oman et al. (2013) in their Fig. 5a. We find that the symmetric response is likewise well simulated by the GMI CTM driven by assimilated meteorology (Fig. 10). However, the free-running GEOS-5 Chemistry Climate Model simulation examined by Oman et al. (2013) produces a single, broad response centered on the Equator (their Fig. 5b) where the vertical wind differences are consistent with the single, centered response. This demonstrates that the ozone response is sensitive to changes in the advective transport that must be well simulated to reproduce the observed tropospheric response.

\subsection{Timing of the response}

As discussed in Sect. 2, sensitivity tests of possible lags in the ozone response in the regression analysis did not increase the correlation between the regressed ozone and Niño 3.4 index or increase the explained variance. In general, the correlation and explained variance remain nearly constant or decreasing with lag times of 1 or 2 months in the middle latitudes. The correlations generally decrease rapidly with longer lag times. This lack of improved regressions using longer lag times indicates that there is minimal impact from long-range transport, including transport in the stratosphere that modulates lower stratospheric ozone concentrations and hence, the magnitude of large-scale stratosphere to troposphere exchange of ozone. This is consistent with previous studies that find little relation between ENSO and large-scale stratosphere-troposphere exchange at midlatitudes (e.g., Hsu and Prather, 2009; Hess et al., 2015). In the present study, the changes to transport and tropopause height contributing to the TCO response act over shorter timescales and potentially impact the entire or large portions of the tropospheric column.

\subsection{Regional aspects of the midlatitude response}

In the middle latitudes, the statistically significant variance explained by ENSO shown in this study occurs over smallscale regions, so it is not surprising that some previous studies fail to find an ENSO influence over large-scale regions or in many surface-based observations. For example, there is 
no statistically significant explained variance over the midlatitude regions of Canada, Central Europe, and Japan considered by Hess et al. (2015). These regions also remain insignificant in the 22-year CTM simulation in the present study.

Conversely, Langford et al. (1998) demonstrate a correlation of ENSO with lidar observations of ozone near Boulder, Colorado from 1993 to 1998. This coincides with the location of significant explained variance and negative sensitivity we show in Figs. 3 and 4. However, Langford et al. (1998) show a positive correlation of mid-tropospheric ozone with the ENSO time series where the ozone signal lags ENSO by a few months. The lidar ozone anomalies are correlated with the subtropical jet exit region in the northeastern Pacific (Langford, 1999). He hypothesizes that transverse circulation across an El Niño-shifted jet exit region brings stratospheric air into subtropical tropical troposphere where it descends with the secondary circulation and is then transported northward to the central United States. In the present study, the suggestion of increased localized stratosphere-totroposphere transport and subsequent downwelling in the northern subtropical Pacific is supported by the meridional cross-section of the anomalous wind field (Fig. 5) and the relatively large TCO response evident in the explained variance and sensitivity (Figs. 3 and 4). It is possible that episodic events may bring anomalously high ozone air to the central United States from the subtropics that can impact at least a portion of the tropospheric column. However, we find that the immediate negative influence by the ENSO-driven vertical transport and tropopause height changes is dominant when considering the entire tropospheric column.

Furthermore, the model evaluation by Lin et al. (2015) reproduces the positive correlation over the Colorado region for the time period studied by Langford et al. (1998), but the correlation is not evident when they consider the longer time period from 1990 to 2012. They show that more frequent springtime stratospheric intrusions following La Niña winters contribute to increased ozone at the surface and free troposphere in the western United States. Since the stratospheric intrusions are associated with enhanced stratosphere to troposphere transport, this can significantly increase the TCO through an influx of ozone-rich air at lower altitudes. The negative sensitivity over the United States shown in the present study is consistent with these results of Lin et al. (2015).

\subsection{South African region}

We find significant explained variance and sensitivity of TCO around subtropical South Africa. This is consistent with the findings of Balashov et al. (2014) who show a correlation of surface observations of ozone with ENSO. They attribute this association to increased ozone formation from anthropogenic emissions under warmer and drier conditions occurring with El Niño.
Unlike most of the midlatitude TCO response, the processes that drive the TCO response in the southern Africa region are not clear considering the mechanisms investigated in this study. A meridional cross-section of the difference in the resolved advective winds averaged between 15 and $55^{\circ} \mathrm{E}$ for strong El Niño and La Niña months (not shown) does not indicate coherent upwelling consistent with the negative sensitivity found there. Overall, there is weak anomalous downward transport between about 5 and $11 \mathrm{~km}$ in this region. The differences in OLR (Fig. 8) are also not consistent with unresolved convection as the source of the negative sensitivity. The tropopause height sensitivity to ENSO in this region (Fig. 9) is positive and similar to the spatial pattern of TCO sensitivity (Fig. 4) but is weak compared to the relatively strong TCO response. Therefore, much of the TCO response may be due to ENSO-related changes in the ozone chemistry, similar to the Balashov et al. (2014) results using surface ozone data, although this requires further investigation beyond the scope of this study.

\section{Summary}

The assimilation of OMI and MLS data enables this first comprehensive study of the TCO response along with the ancillary information to interpret and explain the results. We have used regression analysis of the TCO to provide an observationally constrained evaluation of the magnitude and spatial distribution of the ENSO impact on TCO throughout the middle latitudes. Prior results of the TCO response outside the tropics have been contradictory and limited by the spatial distribution and sparseness of available data. The present study is able to unify and explain many aspects of the seemingly disparate findings reported by previous studies.

While the examination of the response in the tropics is included primarily for completeness and verification of the analyses, we particularly note two results. We find that changes in the large-scale transport dominate the changes in convective transport to produce the TCO response throughout much of the tropics. We also show that a two-lobe response around Indonesia symmetric about the Equator, seen in prior studies of the $2006 \mathrm{El} \mathrm{Niño,} \mathrm{is} \mathrm{not} \mathrm{unique} \mathrm{to} \mathrm{that}$ event.

The midlatitude ozone response to ENSO is not as strong as in the tropics. However, the explained variance is statistically significant over several small regions for the 9-year analysis, such as over the United States and south of New Zealand. Other areas have an explained variance of greater than $10 \%$ that the 22-year CTM simulation suggests would be statistically significant with a longer observation period. These regions include the northern Pacific and around midlatitude South America. 
The TCO sensitivity to ENSO is relatively small but statistically significant over much of the midlatitudes. These regions of negative (positive) sensitivity are coincident with anomalous cyclonic (anticyclonic) circulation. The anomalous circulations are associated with upwelling and downwelling that are consistent with the sign of sensitivity. In addition to the contribution by transport, changes in the tropopause height can contribute substantially to the middle latitude TCO response by altering the depth of the tropospheric column.

This study using analyses of OMI and MLS ozone provides the first explicit spatially resolved characterization of the ENSO influence and demonstrates coherent patterns and teleconnections impacting the TCO in the extratropics. Although relatively weak, the ENSO-driven variability needs to be considered in investigations of midlatitude tropospheric ozone, particularly on regional scales. The spatial variability of the TCO response indicates the ENSO influence is likely statistically insignificant for hemispheric studies or over other broad areas. However, the variance explained by ENSO can be $10 \%$ or greater over smaller regions like the United States, midlatitude South America, and South Africa. Thus, it will be important in attributing the sources of variability and trends in TCO, such as by human-related activity. These results are potentially useful for evaluating the spatially dependent model response of TCO to ENSO forcing. In the extratropics, the ENSO signal is convolved with large extratropical circulation variability from other sources. Thus, additional factors may need to be considered when evaluating the midlatitude response in free-running models, particularly in ensemble simulations.

\section{Data availability}

The assimilated data used in this study are available through the Aura Validation Data Center website: http://avdc.gsfc. nasa.gov. The Niño 3.4 index used in this study is available from the NOAA Climate Prediction Center at http://www. cpc.ncep.noaa.gov/data/indices/. The OLR data are provided by the NOAA/OAR/ESRL PSD, Boulder, Colorado, USA, from their web site at http://www.esrl.noaa.gov/psd/.

Acknowledgements. The authors would like to thank Paul Newman, Jerry Ziemke, Luke Oman, Anne Douglass, and Susan Strahan for helpful discussions. In addition, the authors thank Ray Nassar and three anonymous reviewers for their helpful comments that improved the manuscript. Funding for this research was provided by NASA's Modeling, Analysis and Prediction Program and by NASA NNH12ZDA001N-ACMAP. Simulations and assimilation were done at NASA's Climate Computing Service under awards from HPC.

Edited by: R. Müller

\section{References}

Angell, J. K. and Korshover, J.: Some long-term relations between equatorial sea-surface temperature, the four centers of action and $700 \mathrm{mb}$ flow, J. Clim. Appl. Meteorol., 23, 1326-1332, doi:10.1175/1520-0450(1984)023<1326:SLTRBE>2.0.CO;2, 1984.

Balashov, N. V., Thompson, A. M., Piketh, S. J., and Langerman, K. E.: Surface ozone variability and trends over the South African Highveld from 1990 to 2007, J. Geophys. Res. Atmos., 119, 4323-4342, doi:10.1002/2013JD020555, 2014.

Bey, I., Jacob, D. J., Yantosca, R. M., Logan, J. A., Field, B. D., Fiore, A. M., Li, Q., Liu, H. Y., Mickley, L. J., and Schultz, M. G.: Global modeling of tropospheric chemistry with assimilated meteorology: Model description and evaluation, J. Geophys Res., 106, 23073-23095, doi:10.1029/2001JD000807, 2001.

Chandra, S., Ziemke, J. R., Min, W., and Read, W. G.: Effects of 1997-1998 El Niño on tropospheric ozone and water vapor, Geophys. Res. Lett., 25, 3867-3870, doi:10.1029/98GL02695, 1998.

Chandra, S., Ziemke, J. R., Duncan, B. N., Diehl, T. L., Livesey, N. J., and Froidevaux, L.: Effects of the 2006 El Niño on tropospheric ozone and carbon monoxide: implications for dynamics and biomass burning, Atmos. Chem. Phys., 9, 4239-4249, doi:10.5194/acp-9-4239-2009, 2009.

Climate Prediction Center: Monthly Atmospheric \& SST Indices: available at: http://www.cpc.ncep.noaa.gov/data/indices/, last access: 31 May 2016.

DeWeaver, E. and Nigam, S.: Linearity in ENSO's atmospheric response, J. Climate, 15, 2446-2461, doi:10.1175/15200442(2002)015<2446:LIESAR>2.0.CO;2, 2002.

Doherty, R. M., Stevenson, D. S., Johnson, C. E., Collins, W. J., and Sanderson, M. G.: Tropospheric ozone and El Niño-Southern Oscillation: Influence of atmospheric dynamics, biomass burning emissions, and future climate change, J. Geophys. Res., 111, D19304, doi:10.1029/2005JD006849, 2006.

Draper, N. R. and Smith, H.: Applied Regression Analysis, John Wiley \& Sons, Inc., Hoboken, NJ, USA, 1998.

Duncan, B. N., West, J. J., Yoshida, Y., Fiore, A. M., and Ziemke, J. R.: The influence of European pollution on ozone in the Near East and northern Africa, Atmos. Chem. Phys., 8, 2267-2283, doi:10.5194/acp-8-2267-2008, 2008.

Fishman, J., Watson, C. E., Larsen, J. C., and Logan, J. A.: Distribution of tropospheric ozone determined from satellite data, J. Geophys. Res., 95, 3599, doi:10.1029/JD095iD04p03599, 1990.

Fishman, J., Wozniak, A. E., and Creilson, J. K.: Global distribution of tropospheric ozone from satellite measurements using the empirically corrected tropospheric ozone residual technique: Identification of the regional aspects of air pollution, Atmos. Chem. Phys., 3, 893-907, doi:10.5194/acp-3-893-2003, 2003.

Fishman, J., Creilson, J. K., Wozniak, A. E., and Crutzen, P. J.: Interannual variability of stratospheric and tropospheric ozone determined from satellite measurements, J. Geophys. Res., 110, D20306, doi:10.1029/2005JD005868, 2005.

Fujiwara, M., Kita, K., Kawakami, S., Ogawa, T., Komala, N., Saraspriya, S., and Suripto, A.: Tropospheric ozone enhancements during the Indonesian Forest Fire Events in 1994 and in 1997 as revealed by ground-based observations, Geophys. Res. Lett., 26, 2417-2420, doi:10.1029/1999GL900117, 1999.

García-Herrera, R., Calvo, N., Garcia, R. R., and Giorgetta, M. A.: Propagation of ENSO temperature signals into the middle 
atmosphere: A comparison of two general circulation models and ERA-40 reanalysis data, J. Geophys. Res., 111, D06101, doi:10.1029/2005JD006061, 2006.

Hess, P., Kinnison, D., and Tang, Q.: Ensemble simulations of the role of the stratosphere in the attribution of northern extratropical tropospheric ozone variability, Atmos. Chem. Phys., 15, 23412365, doi:10.5194/acp-15-2341-2015, 2015.

Hsu, J. and Prather, M. J.: Stratospheric variability and tropospheric ozone, J. Geophys. Res., 114, D06102, doi:10.1029/2008JD010942, 2009.

Langford, A. O.: Stratosphere troposphere exchange at the subtropical jet: Contribution to the tropospheric ozone budget at midlatitudes, Geophys. Res. Lett., 26, 2449-2452, doi:10.1029/1999GL900556, 1999.

Langford, A. O., O'Leary, T. J., Masters, C. D., Aikin, K. C., and Proffitt, M. H.: Modulation of middle and upper tropospheric ozone at northern midlatitudes by the El Niño/Southern Oscillation, Geophys. Res. Lett., 25, 2667-2670, 1998.

Lee, H.-T.: Climate Algorithm Theoretical Basis Document (C-ATBD): Outgoing Longwave Radiation (OLR) - Daily. NOAA's Climate Data Record (CDR) Program, CDRPATBD-0526, 46 pp., available at: http://www1.ncdc.noaa.gov/ pub/data/sds/cdr/CDRs/OutgoingLongwaveRadiation-Daily/ AlgorithmDescription.pdf (last access: 31 May 2016), 2014.

Lee, S., Shelow, D. M., Thompson, A. M., and Miller, S. K.: QBO and ENSO variability in temperature and ozone from SHADOZ, 1998-2005, J. Geophys. Res., 115, D18105, doi:10.1029/2009JD013320, 2010.

Levelt, P. F., van den Oord, G. H. J., Dobber, M. R., Malkki, A., Huib, V., de Vries, J., Stammes, P., Lundell, J. O. V., and Saari, H.: The ozone monitoring instrument, IEEE Trans. Geosci. Remote Sens., 44, 1093-1101, doi:10.1109/TGRS.2006.872333, 2006.

Lin, M., Horowitz, L. W., Oltmans, S. J., Fiore, A. M., and Fan, S.: Tropospheric ozone trends at Mauna Loa Observatory tied to decadal climate variability, Nat. Geosci., 7, 136-143, doi:10.1038/NGEO2066, 2014.

Lin, M., Fiore, A. M., Horowitz, L. W., Langford, A. O., Oltmans, S. J., Tarasick, D., and Reider, H. E.: Climate variability modulates western US ozone air quality in spring via deep stratospheric intrusions, Nat. Commun., 6, 7105, doi:10.1038/ncomms8105, 2015.

Livesey, N. J., Read, W. G., Froidevaux, L., Lambert, A., Manney, G. L., Pumphrey, H. C., Santee, M. L., Schwartz, M. J., Wang, S., Cofield, R. E., Cuddy, D. T., Fuller, R. A., Jarnot, R. F., Jiang, J. H., Knosp, B. W., Stek, P. C., Wagner, P. A., and Wu, D. L.: Version 3.3 Level 2 data quality and description document, Technical report, Jet Propulsion Laboratory, D-33509, 2011.

Logan, J. A., Megretskaia, I. A., Miller, A. J., Tiao, G. C., Choi, D., Zhang, L., Stolarski, R. S., Labow, G. J., Hollandsworth, S. M., and Bodeker, G. E.: Trends in the vertical distribution of ozone: A comparison of two analyses of ozonesonde data, J. Geophys. Res., 104, 26373-26399, 1999.

Mo, K. C. and Livezey, R. E.: Tropical-extratropical geopotential height teleconnections during the Northern Hemisphere winter, Mon. Weather Rev., 114, 2488-2515, doi:10.1175/15200493(1986)114<2488:TEGHTD>2.0.CO;2, 1986.

Nassar, R., Logan, J. A., Megretskaia, I. A., Murray, L. T., Zhang, L., and Jones, D. B. A.: Analysis of tropical tropospheric ozone, carbon monoxide, and water vapor during the 2006 El Niño using TES observations and the GEOS-Chem model, J. Geophys. Res., 114, D17304, doi:10.1029/2009JD011760, 2009.

Neu, J. L., Flury, T., Manney, G. L., Santee, M. L., Livesey, N. J., and Worden, J.: Tropospheric ozone variations governed by changes in stratospheric circulation, Nat. Geosci., 7, 340-344, doi:10.1038/ngeo2138, 2014.

Oman, L. D., Ziemke, J. R., Douglass, A. R., Waugh, D. W., Lang, C., Rodriguez, J. M., and Nielsen, J. E.: The response of tropical tropospheric ozone to ENSO, Geophys. Res. Lett., 38, L13706, doi:10.1029/2011GL047865, 2011.

Oman, L. D., Douglass, A. R., Ziemke, J. R., Rodriguez, J. M., Waugh, D. W., and Nielsen, J. E.: The ozone response to ENSO in Aura satellite measurements and a chemistryclimate simulation, J. Geophys. Res. Atmos., 118, 965-976, doi:10.1029/2012JD018546, 2013.

Rienecker, M. M., Suarez, M. J., Gelaro, R., Todling, R., Bacmeister, J., Liu, E., Bosilovich, M. G., Schubert, S. D., Takacs, L., Kim, G.-K., Bloom, S., Chen, J., Collins, D., Conaty, A., da Silva, A., Gu, W., Joiner, J., Koster, R. D., Lucchesi, R., Molod, A., Owens, T., Pawson, S., Pegion, P., Redder, C. R., Reichle, R., Robertson, F. R., Ruddick, A. G., Sienkiewicz, M., and Woollen, J.: MERRA: NASA's Modern-Era Retrospective Analysis for Research and Applications, J. Climate, 24, 3624-3648, doi:10.1175/JCLI-D-11-00015.1, 2011.

Schoeberl, M. R., Ziemke, J. R., Bojkov, B., Livesey, N., Duncan, B., Strahan, S., Froidevaux, L., Kulawik, S., Bhartia, P. K., Chandra, S., Levelt, P. F., Witte, J. C., Thompson, A. M., Cuevas, E., Redondas, A., Tarasick, D. W., Davies, J., Bodeker, G., Hansen, G., Johnson, B. J., Oltmans, S. J., Vömel, H., Allaart, M., Kelder, H., Newchurch, M., Godin-Beekmann, S., Ancellet, G., Claude, H., Andersen, S. B., Kyrö, E., Parrondos, M., Yela, M., Zablocki, G., Moore, D., Dier, H., von der Gathen, P., Viatte, P., Stübi, R., Calpini, B., Skrivankova, P., Dorokhov, V., de Backer, H., Schmidlin, F. J., Coetzee, G., Fujiwara, M., Thouret, V., Posny, F., Morris, G., Merrill, J., Leong, C. P., Koenig-Langlo, G., and Joseph, E.: A trajectory-based estimate of the tropospheric ozone column using the residual method, J. Geophys. Res., 112, D24S49, doi:10.1029/2007JD008773, 2007.

Stevenson, D., Doherty, R., Sanderson, M., Johnson, C., Collins, B., and Derwent, D.: Impacts of climate change and variability on tropospheric ozone and its precursors, Faraday Discuss., 130, 41-57, doi:10.1039/B417412G, 2005.

Strahan, S. E., Duncan, B. N., and Hoor, P.: Observationally derived transport diagnostics for the lowermost stratosphere and their application to the GMI chemistry and transport model, Atmos. Chem. Phys., 7, 2435-2445, doi:10.5194/acp-7-2435-2007, 2007.

Strode, S. A., Rodriguez, J. M., Logan, J. A., Cooper, O. R., Witte, J. C., Lamsal, L. N., Damon, M., Van Aartsen, B., Steenrod, S. D., and Strahan, S. E.: Trends and variability in surface ozone over the United States, J. Geophys. Res. Atmos., 120, 9020 9042, doi:10.1002/2014JD022784, 2015.

Sudo, K. and Takahashi, M.: Simulation of tropospheric ozone changes during 1997-1998 El Niño: Meteorological impact on tropospheric photochemistry, Geophys. Res. Lett., 28, 40914094, doi:10.1029/2001GL013335, 2001.

Thompson, A. M. and Hudson, R. D.: Tropical tropospheric ozone (TTO) maps from Nimbus 7 and Earth Probe TOMS by the 
modified-residual method: Evaluation with sondes, ENSO signals, and trends from Atlantic regional time series, J. Geophys. Res., 104, 26961-26975, doi:10.1029/1999JD900470, 1999.

Thompson, A. M., Witte, J. C., Hudson, R. D., Guo, H., Herman, J. R., and Fujiwara, M.: Tropical Tropospheric Ozone and Biomass Burning, Science, 291, 2128-2132, doi:10.1126/science.291.5511.2128, 2001.

Thompson, A. M., Balashov, N. V., Witte, J. C., Coetzee, J. G. R., Thouret, V., and Posny, F.: Tropospheric ozone increases over the southern Africa region: bellwether for rapid growth in Southern Hemisphere pollution?, Atmos. Chem. Phys., 14, 9855-9869, doi:10.5194/acp-14-9855-2014, 2014.

Tiao, G. C., Reinsel, G. C., Xu, D., Pedrick, J. H., Zhu, X., Miller, A. J., DeLuisi, J. J., Mateer, C. L., and Wuebbles, D. J.: Effects of autocorrelation and temporal sampling schemes on estimates of trend and spatial correlation, J. Geophys. Res., 95, 20507, doi:10.1029/JD095iD12p20507, 1990.

Trenberth, K. E.: The Definition of El Niño, B. Am. Meteorol. Soc., 78, 2771-2777, doi:10.1175/15200477(1997)078<2771:TDOENO> 2.0.CO;2, 1997.

Trenberth, K. E., Branstator, G. W., Karoly, D., Kumar, A., Lau, N.C., and Ropelewski, C.: Progress during TOGA in understanding and modeling global teleconnections associated with tropical sea surface temperatures, J. Geophys. Res., 103, 14291-14324, doi:10.1029/97JC01444, 1998.

Trenberth, K. E., Caron, J. M., Stepaniak, D. P., and Worley, S.: Evolution of El Niño-Southern Oscillation and global atmospheric surface temperatures, J. Geophys. Res., 107, 4065, doi:10.1029/2000JD000298, 2002.

Vigouroux, C., Blumenstock, T., Coffey, M., Errera, Q., García, O., Jones, N. B., Hannigan, J. W., Hase, F., Liley, B., Mahieu, E., Mellqvist, J., Notholt, J., Palm, M., Persson, G., Schneider, M., Servais, C., Smale, D., Thölix, L., and De Mazière, M.: Trends of ozone total columns and vertical distribution from FTIR observations at eight NDACC stations around the globe, Atmos. Chem. Phys., 15, 2915-2933, doi:10.5194/acp-15-2915-2015, 2015.
Wargan, K., Pawson, S., Olsen, M. A., Witte, J. C., Douglass, A. R., Ziemke, J. R., Strahan, S. E., and Nielsen, J. E.: The global structure of upper troposphere-lower stratosphere ozone in GEOS-5: A multiyear assimilation of EOS Aura data, J. Geophys. Res. Atmos., 120, 2013-2036, doi:10.1002/2014JD022493, 2015.

Zeng, G. and Pyle, J. A.: Influence of El Niño Southern Oscillation on stratosphere/troposphere exchange and the global tropospheric ozone budget, Geophys. Res. Lett., 32, L01814, doi:10.1029/2004GL021353, 2005.

Ziemke, J. R. and Chandra, S.: La Nina and El Nino induced variabilities of ozone in the tropical lower atmosphere during 1970-2001, Geophys. Res. Lett., 30, 1142, doi:10.1029/2002GL016387, 2003.

Ziemke, J. R., Chandra, S., and Bhartia, P. K.: Two new methods for deriving tropospheric column ozone from TOMS measurements: Assimilated UARS MLS/HALOE and convective-cloud differential techniques, J. Geophys. Res., 103, 22115-22127, doi:10.1029/98JD01567, 1998.

Ziemke, J. R., Chandra, S., Oman, L. D., and Bhartia, P. K.: A new ENSO index derived from satellite measurements of column ozone, Atmos. Chem. Phys., 10, 3711-3721, doi:10.5194/acp10-3711-2010, 2010.

Ziemke, J. R., Olsen, M. A., Witte, J. C., Douglass, A. R., Strahan, S. E., Wargan, K., Liu, X., Schoeberl, M. R., Yang, K., Kaplan, T. B., Pawson, S., Duncan, B. N., Newman, P. A., Bhartia, P. K., and Heney, M. K.: Assessment and applications of NASA ozone data products derived from Aura OMI/MLS satellite measurements in context of the GMI chemical transport model, J. Geophys. Res. Atmos., 119, 5671-5699, doi:10.1002/2013JD020914, 2014.

Ziemke, J. R., Douglass, A. R., Oman, L. D., Strahan, S. E., and Duncan, B. N.: Tropospheric ozone variability in the tropics from ENSO to MJO and shorter timescales, Atmos. Chem. Phys., 15, 8037-8049, doi:10.5194/acp-15-8037-2015, 2015. 